\title{
Reactive Intermediates Formed During Olefin Polymerization by Methylalumoxane-Activated ansa-Zirconocene Catalysts: Identification of a Chain-Carrying Intermediate by NMR Methods
}

\author{
Dmitrii E. Babushkin ${ }^{\star, \dagger}$ and Hans H. Brintzinger ${ }^{\star, \neq}$ \\ Boreskov Institute of Catalysis, Siberian Branch of Russian Academy of Science, Pr. Lavrentieva 5, \\ Novosibirsk, RU-630090, Russia, and Fachbereich Chemie, Universität Konstanz, D-78457 Konstanz, Germany
}

Received October 28, 2009; E-mail: Dimi@catalysis.ru; hans.brintzinger@uni-konstanz.de

The growth of polyolefin chains in zirconocene-based catalyst systems is generally agreed to occur by olefin insertion into the $\mathrm{Zr}$-polymer bond of a reaction complex of the type $\left[\mathrm{Cp}^{x}{ }_{2} \mathrm{Zr}-\right.$ polymer(olefin) $]^{+} \mathrm{A}^{-}$, where $\mathrm{Cp}^{x}{ }_{2}$ is a pair of annulated, substituted, and/or bridged $\mathrm{C}_{5}$-ring ligands and $\mathrm{A}^{-}$a weakly coordinating anion. ${ }^{1}$ Much less certain, however, is the nature of the resting state(s) in "working" catalyst systems, i.e. of those species, which comprise major parts of the total catalyst content. Probable catalyst resting states are contact ion pairs of the type $\left[\mathrm{Cp}^{x}{ }_{2} \mathrm{Zr}\right.$-polymer $\left.{ }^{+} \cdots \mathrm{A}^{-}\right]$, observed by Landis and co-workers in catalyst systems activated by $\mathrm{B}\left(\mathrm{C}_{6} \mathrm{~F}_{5}\right)_{3}$ at $-40{ }^{\circ} \mathrm{C},{ }^{2}$ or zirconocene-polymeryl cations, $\left[\mathrm{Cp}^{x}{ }_{2} \mathrm{Zr}\right.$ polymer $]^{+}$, proposed by Bochmann and co-workers to be sufficiently stabilized by an agostic $\mathrm{Zr}$-alkyl bond to relegate the anion $\mathrm{A}^{-}$to outer-sphere association. ${ }^{3}$

Cationic species with a reduced propensity for further olefin insertion, carrying at their $\mathrm{Zr}$ center e.g. a regioirregular monomer unit $^{4}$ or an allyl-ended polymer chain, ${ }^{5}$ have likewise been proposed to represent abundant species in "working" catalysts. Little experimental evidence is available however with regard to the species actually arising as resting states in polymerization catalysts at or above ambient temperature and in the presence of a large olefin excess, in particular in catalyst systems activated, as it is most frequently done, by methylalumoxane (MAO).

\section{Scheme 1}
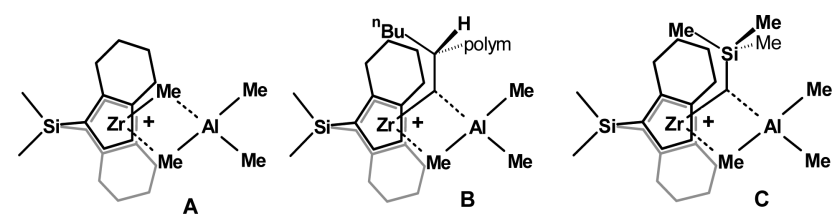

(SBI) $\mathrm{ZrMe}_{2} / \mathrm{MAO}$ mixtures without added olefin show in their ${ }^{1} \mathrm{H}$ NMR spectra in $\mathrm{C}_{6} \mathrm{D}_{6}$ solution the signals of the cationic $\mathrm{AlMe}_{3}$ adduct $\left[(\mathrm{SBI}) \mathrm{Zr}(\mu-\mathrm{Me})_{2} \mathrm{AlMe}_{2}\right]^{+}($Scheme $1 \mathrm{~A})$ and broad features of the ion pair $\left[(\mathrm{SBI}) \mathrm{ZrMe}^{+} \cdot \cdot \mathrm{MeMAO}^{-}\right],{ }^{6}$ both of which are present in comparable amounts under these conditions (Figure 1, Table 1). ${ }^{7}$ When 1-hexene is added to such a solution in a ratio of [hexene]/[Zr] $=1000$, one observes, together with a rapid polymerization of hexene $\left(t_{1 / 2} \approx 5 \mathrm{~min}\right)$, a similarly rapid diminution of the signals of the cation $\left[(\mathrm{SBI}) \mathrm{Zr}(\mu-\mathrm{Me})_{2} \mathrm{AlMe}_{2}\right]^{+}$to $\sim 30 \%$ of their previous intensity. Later, these signals increase in size again, reaching ca. $80 \%$ of their previous intensity after $\sim 1 \mathrm{~h}$ (Figures 1 and $2 \mathrm{a}$ ).

Together with the diminution of the $\left[(\mathrm{SBI}) \mathrm{Zr}(\mu-\mathrm{Me})_{2} \mathrm{AlMe}_{2}\right]^{+}$ signals, a new set of signals is growing in, with $\mathrm{C}_{5}-H$ ligand signals at a slightly lower and a $\operatorname{Zr}(\mu-\mathrm{Me}) \mathrm{Al}$ signal at a slightly higher

Siberian Branch of Russian Academy of Science.

\$ Universität Konstanz.

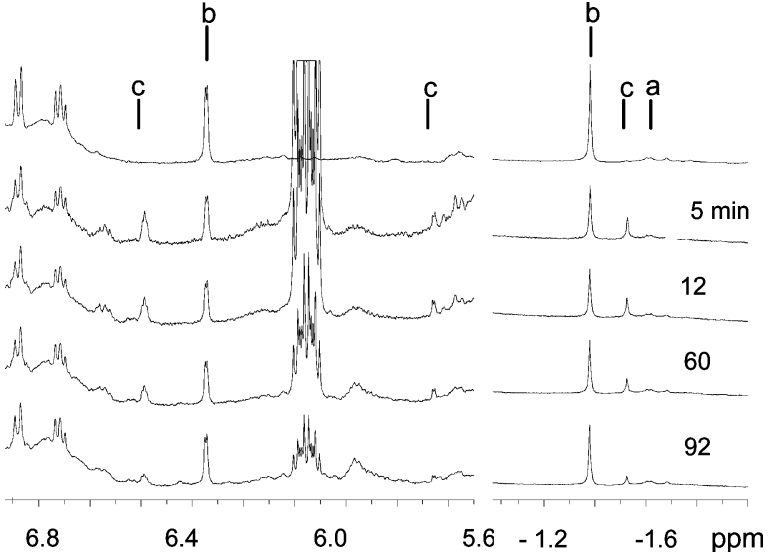

Figure 1. ${ }^{1} \mathrm{H} \mathrm{NMR}$ spectra of an (SBI)ZrMe 2 /MAO solution before addition of 1-hexene (top trace) and 5 to 92 min after addition of 1-hexene $\left(\mathrm{C}_{6} \mathrm{D}_{6}\right.$, $300 \mathrm{~K},[\mathrm{Zr}]_{\mathrm{tot}}=0.6 \mathrm{mM}$; [hexene $]_{\text {init }} /[\mathrm{Zr}]=1000 ;[\mathrm{Al}]_{\mathrm{MAO}} /[\mathrm{Zr}]=960$ ); ligand $\mathrm{C}_{5}-\mathrm{H}$ region (left) and $\mathrm{Zr}-\mathrm{CH}_{3}$ region (right); signals due to $\left[(\mathrm{SBI}) \mathrm{ZrMe}^{+} \cdot \mathrm{MeMAO}^{-}\right](\mathrm{a})$, to $\left[(\mathrm{SBI}) \mathrm{Zr}(\mu-\mathrm{Me})_{2} \mathrm{AlMe}_{2}\right]^{+}$(b), and to $\left[(\mathrm{SBI}) \mathrm{Zr}(\mu-\mathrm{R})(\mu-\mathrm{Me}) \mathrm{AlMe}_{2}\right]^{+}$(c).

Table 1. ${ }^{1} \mathrm{H}$ NMR Signals of Cationic (SBI)Zr Complexes ${ }^{a}$

\begin{tabular}{|c|c|c|c|c|c|}
\hline & $\begin{array}{c}\mathrm{C}_{6}- \\
\mathrm{H}\end{array}$ & $\begin{array}{l}\mathrm{C}_{5}- \\
H(3)\end{array}$ & $\begin{array}{l}\mathrm{C}_{5}- \\
H(2)\end{array}$ & $\mathrm{Me}_{\text {term }}$ & $\mu$-Me \\
\hline$\left[(\mathrm{SBI}) \mathrm{ZrMe}^{+} \cdot \cdots \mathrm{MeMAO}^{-}\right]^{b}$ & & $\begin{array}{l}5.7- \\
6.0\end{array}$ & $\begin{array}{l}5.1- \\
5.2\end{array}$ & $\begin{array}{l}-1.6 \\
\text { (br) }\end{array}$ & \\
\hline$\left[(\mathrm{SBI}) \mathrm{Zr}(\mu-\mathrm{Me})_{2} \mathrm{AlMe}_{2}\right]^{+b, c}$ & $6.71^{d}$ & $6.13^{e}$ & $4.98^{e}$ & -0.65 & $-1.39^{f}$ \\
\hline$[(\mathrm{SBI}) \mathrm{Zr}(\mu-\mathrm{R})-$ & $6.55^{d}$ & $6.39^{e}$ & $4.91^{e, h}$ & n.o. & $-1.53^{g}$ \\
\hline$\left.(\mu-\mathrm{Me}) \mathrm{AlMe}_{2}\right]^{+c}$ & & $6.38^{e}$ & $5.26^{e}$ & & \\
\hline$\left[(\mathrm{SBI}) \mathrm{Zr}\left(\mu-\mathrm{CH}_{2} \mathrm{SiMe}_{3}\right)-\right.$ & $6.52^{d}$ & $6.08^{e}$ & $5.16^{e}$ & -0.63 & $-1.37^{g}$ \\
\hline$\left.(\mu-\mathrm{Me}) \mathrm{AlMe}_{2}\right]^{+c, i}$ & $6.73^{d}$ & $6.58^{e}$ & $5.17^{e}$ & -0.80 & \\
\hline
\end{tabular}

${ }^{a} \mathrm{C}_{6} \mathrm{D}_{6}, 300 \mathrm{~K}, 400 \mathrm{MHz}, \delta$ in ppm. ${ }^{b}$ Reference $6 \mathrm{c} .{ }^{c} \mathrm{MeMAO}^{-}$as counteranion. ${ }^{d}$ Pseudotriplets with $J_{\mathrm{HH}} 7.6-8.0 \mathrm{~Hz}$. ${ }^{e}$ Doublets with $J_{\mathrm{HH}}$ 3.2-3.5 Hz. ${ }^{f}$ Two $\mu$-Me groups per zirconocene unit. ${ }^{g}$ One $\mu$-Me group per zirconocene unit. ${ }^{h}$ Observed during polymerization of $1-{ }^{13} \mathrm{C}$-1-hexene. ${ }^{i}$ At $20{ }^{\circ} \mathrm{C}$, further signals: $\mathrm{Zr}-\mathrm{CH}_{2}-0.91 \mathrm{ppm}(\mathrm{d}, 5.7$ $\mathrm{Hz}),-3.54 \mathrm{ppm}(\mathrm{d}, 5.7 \mathrm{~Hz}), \mathrm{Me}_{2} \mathrm{Si} 0.81 \mathrm{ppm}(3 \mathrm{H}), 0.72 \mathrm{ppm}(3 \mathrm{H})$, $\mathrm{Me}_{3} \mathrm{Si}-0.11 \mathrm{ppm}(9 \mathrm{H})$.

field than that of the respective $\left[(\mathrm{SBI}) \mathrm{Zr}(\mu-\mathrm{Me})_{2} \mathrm{AlMe}_{2}\right]^{+}$signals (Figure 1, Table 1). ${ }^{8}$ As judged by the integrals of its $\mathrm{C}_{5}-H$ ligand and $\operatorname{Zr}(\mu-\mathrm{Me})$ signals, this species contains only a single $\mu$-Me group. Based on this observation and on the general similarity of its NMR characteristics to those of $\left[(\mathrm{SBI}) \mathrm{Zr}(\mu-\mathrm{Me})_{2} \mathrm{AlMe}_{2}\right]^{+}$, we propose for this species a formula $\left[(\mathrm{SBI}) \mathrm{Zr}(\mu-\mathrm{R})(\mu-\mathrm{Me}) \mathrm{AlMe}_{2}\right]^{+}$, where $\mathrm{R}$ is a polyhexyl chain. Chain-carrying $\mathrm{AlMe}_{3}$ adducts of this type have been suspected before to arise during olefin polymerization catalysis ${ }^{6 \mathrm{~b}, 9}$ but have escaped detection up to now. Our assignment is supported by the following observations.

While the size of the signals of $\left[(\mathrm{SBI}) \mathrm{Zr}(\mu-\mathrm{R})(\mu-\mathrm{Me}) \mathrm{AlMe}_{2}\right]^{+}$ is rather independent of residual hexene concentration in the range 


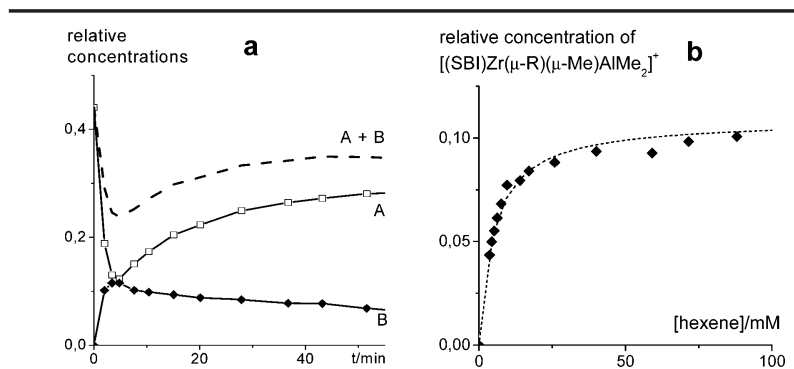

Figure 2. (a) Time-dependent concentration changes of the cations $\left[(\mathrm{SBI}) \mathrm{Zr}(\mu-\mathrm{Me})_{2} \mathrm{AlMe}_{2}\right]^{+}(\mathrm{A})$ and $\left[(\mathrm{SBI}) \mathrm{Zr}(\mu-\mathrm{R})(\mu-\mathrm{Me}) \mathrm{AlMe}_{2}\right]^{+}(\mathrm{B})$ and of their sum; (b) concentration of the cation $\left[(\mathrm{SBI}) \mathrm{Zr}(\mu-\mathrm{R})(\mu-\mathrm{Me}) \mathrm{AlMe}_{2}\right]^{+}$in dependence of the residual hexene concentration; all relative to the total zirconocene concentration. Reaction conditions same as those in Figure 1.

of $100>$ [hexene $_{\text {resid }}>40 \mathrm{mM}$, it decreases in parallel to the hexene concentration in the range [hexene $]_{\text {resid }}<25 \mathrm{mM}$, i.e. when the [hexene $]_{\text {resid }} /[\mathrm{Zr}]$ ratio falls below a value of ca. 40 (Figure $2 \mathrm{~B}$ ). This hexene dependence of its steady-state concentration indicates that the cation $\left[(\mathrm{SBI}) \mathrm{Zr}(\mu-\mathrm{R})(\mu-\mathrm{Me}) \mathrm{AlMe}_{2}\right]^{+}$requires for its formation the concurrent consumption of hexene, ${ }^{10}$ in accord with the view that it contains as its $\mathrm{R}$ component a polyhexyl chain.

Since heterobinuclear zirconocene cations with bridging $\mathrm{R}$ groups other than $\mathrm{R}=$ Me have rarely been described so far, ${ }^{6 \mathrm{~b}}$ we have generated, by reaction of $\left[(\mathrm{SBI}) \mathrm{Zr}-\mathrm{CH}_{2} \mathrm{SiMe}_{3}\right]^{+} \mathrm{B}\left(\mathrm{C}_{6} \mathrm{~F}_{5}\right)_{4}{ }^{-}$with 10-30 equiv. $\mathrm{AlMe}_{3}$ or of ( $\left.\mathrm{SBI}\right) \mathrm{Zr}(\mathrm{Me}) \mathrm{CH}_{2} \mathrm{SiMe}_{3}$ with $\mathrm{MAO}$, the cation $\left[(\mathrm{SBI}) \mathrm{Zr}\left(\mu-\mathrm{CH}_{2} \mathrm{SiMe}_{3}\right)(\mu-\mathrm{Me}) \mathrm{AlMe}_{2}\right]^{+}$(Scheme 1C). This model complex, which is converted by excess $\mathrm{AlMe}_{3}$ with $t_{1 / 2} \approx$ 10 min to the cation $\left[(\mathrm{SBI}) \mathrm{Zr}(\mu-\mathrm{Me})_{2} \mathrm{AlMe}_{2}\right]^{+}$, gives rise to $\mathrm{Zr}(\mu$ $\mathrm{Me}) \mathrm{Al}$ and $\mathrm{C}_{5}-H$ NMR signals similar to those of the cation $\left[(\mathrm{SBI}) \mathrm{Zr}(\mu-\mathrm{R})(\mu-\mathrm{Me}) \mathrm{AlMe}_{2}\right]^{+}$(Table 1$) .{ }^{11}$ While this similarity can be taken as support for our structural assignment of the latter, diastereotopic $\mathrm{Zr}-\mathrm{CH}_{2}$ signals, apparent at -0.91 and $-3.54 \mathrm{ppm}$ for $\left[(\mathrm{SBI}) \mathrm{Zr}\left(\mu-\mathrm{CH}_{2} \mathrm{SiMe}_{3}\right)(\mu-\mathrm{Me}) \mathrm{AlMe}_{2}\right]^{+}$, are not detectable for $\left[(\mathrm{SBI}) \mathrm{Zr}(\mu-\mathrm{R})(\mu-\mathrm{Me}) \mathrm{AlMe}_{2}\right]^{+}$, due to their insufficient intensity. ${ }^{12}$

To provide unequivocal evidence for the presence of a $\mathrm{Zr}-\mathrm{CH}_{2}$ junction in $\left[(\mathrm{SBI}) \mathrm{Zr}(\mu-\mathrm{R})(\mu-\mathrm{Me}) \mathrm{AlMe}_{2}\right]^{+}$, we have studied the polymerization of $1-{ }^{13} \mathrm{C}-1$-hexene by the same catalyst system. When $1-{ }^{13} \mathrm{C}-1$-hexene is added to an (SBI)ZrMe $2 / \mathrm{MAO}$ solution, one observes the appearance of two weak ${ }^{13} \mathrm{C}$ signals. A first signal at $80.6 \mathrm{ppm}$ appears immediately and then decays rather fast, in parallel to the ${ }^{1} \mathrm{H}$ signal of $\left[(\mathrm{SBI}) \mathrm{Zr}(\mu-\mathrm{R})(\mu-\mathrm{Me}) \mathrm{AlMe}_{2}\right]^{+}$at -1.55 $\mathrm{ppm}$, while the second signal at $84.6 \mathrm{ppm}$ appears after reaction times of 10-15 min, continues to grow for ca. $30 \mathrm{~min}$, and then decays slowly over a period of several hours.

This latter signal is shown, by INEPT methods (s. Supporting Information), to be due to a $\mathrm{CH}_{2}$ group with a $J_{\mathrm{H}, \mathrm{C}}$ coupling constant of $149 \mathrm{~Hz}$. Such a value is typical for $\mathrm{Zr}$-bound allyl groups, as documented by Landis and co-workers for catalyst systems activated with $\mathrm{Ph}_{3} \mathrm{C}^{+} \mathrm{B}\left(\mathrm{C}_{6} \mathrm{~F}_{5}\right)_{4}{ }^{-5 b}$ Some species with allyl-ended polymer chains, yet to be characterized in more detail, thus appear to arise also in MAO-activated zirconocene catalysts.

The ${ }^{13} \mathrm{C}$ signal at $80.6 \mathrm{ppm}$ however, which is associated with the cation $\left[(\mathrm{SBI}) \mathrm{Zr}(\mu-\mathrm{R})(\mu-\mathrm{Me}) \mathrm{AlMe}_{2}\right]^{+}$, is shown by its INEPT signal to be due to a $\mathrm{CH}_{2}$ group with a $J_{\mathrm{H}, \mathrm{C}}$ coupling constant of $107 \mathrm{~Hz}$ (s. Supporting Information). The rather small coupling constant of this signal as well as its chemical shift are entirely consistent with its assignment to a $\mathrm{Zr}$-bound $\mathrm{CH}_{2}$ group (cf. Supporting Information $)^{2,5 b, 13}$ and thus in accord with the notion that this cation does indeed carry a polyhexyl chain.

The concentration changes of $\left[(\mathrm{SBI}) \mathrm{Zr}(\mu-\mathrm{Me})_{2} \mathrm{AlMe}_{2}\right]^{+}$and $\left[(\mathrm{SBI}) \mathrm{Zr}(\mu-\mathrm{R})(\mu-\mathrm{Me}) \mathrm{AlMe}_{2}\right]^{+}$are correlated in the sense that the latter reaches its maximum at the same time (4-5 min), at which the former goes through its minimum (Figure 2a). However, the concentrations of all the species, observed by the NMR methods described above, account in toto for less than half of the total zirconocene concentration. Large parts of the catalyst content must thus be present in the form of some species, which are not detected by the NMR methods used.

While contact-ion pairs such as [(SBI)Zr-polymer $\left.{ }^{+} . . \mathrm{MeMAO}^{-}\right]$ might give rise to very broad signals, due to their nonuniformity, and thus escape detection, further studies are clearly needed to clarify the nature of any "NMR-silent" species and their roles in the catalytic polymerization process. Our observation of a chaincarrying cation and time-dependent concentration profiles for this and other species during MAO-activated olefin polymerization provides experimental access toward this goal.

Acknowledgment. We thank Dr. M. Ringwald, MCAT GmbH, Konstanz, and Prof. M. Bochmann and Dr. S. Lancaster, University of East Anglia, Norwich, for donations of samples of (SBI)ZrMe $\mathrm{Zn}_{2}$ and (SBI)Zr(Me) $\left(\mathrm{CH}_{2} \mathrm{SiMe}_{3}\right)$, respectively, Chemtura $\mathrm{GmbH}$, Bergkamen, for samples of methylalumoxane, and Ms. Evelyn Wuttke for help with the preparation of ${ }^{13} \mathrm{C}$-labeled 1-hexene. Support of this work by the Russian Academy of Science, by Deutsche Forschungsgemeinschaft (Grant ME 1388/9-1), by BASELL GmbH, and by Fonds der Chemischen Industrie is gratefully acknowledged. For helpful discussions we thank Prof. E. P. Talsi (Boreskov Institute of Catalysis) and Prof. M. Bochmann (University of East Anglia).

Supporting Information Available: Experimental details of ${ }^{1} \mathrm{H}$ NMR studies on catalyst speciation, generation and ${ }^{1} \mathrm{H}$ NMR spectra of the cation $\left[(\mathrm{SBI}) \mathrm{Zr}\left(\mu-\mathrm{CH}_{2} \mathrm{SiMe}_{3}\right)(\mu-\mathrm{Me}) \mathrm{AlMe}_{2}\right]^{+}$, details of NMR studies with ${ }^{13} \mathrm{C}$-labeled 1 -hexene and of signal assignments. This material is available free of charge via the Internet at http://pubs.acs.org.

\section{References}

(1) Reviews: (a) Resconi, L. Cavallo, L ; Fait, A. Piemontesi, F Chem. Rev. 2000, 100, 1253. (b) Chen, E. Y.-X.; Marks, T. J. Chem. Rev. 2000, 100, 1391. (c) Bochmann, M. J. Organomet. Chem. 2004, 689, 3982.

(2) (a) Landis, C. R.; Rosaaen, K. A.; Sillars, D. R. J. Am. Chem. Soc. 2003, 125, 1710. (b) Sillars, D. R.; Landis, C. R. J. Am. Chem. Soc. 2003, 125, 9894.

(3) M. Song, F.; Lancaster, S. J.; Cannon, R. D.; Schormann, M.; Humphrey, S. M.; Zuccacia, C.; Macchioni, A.; Bochmann, M. Organometallics 2005, 24,1315 .

(4) (a) Busico, V.; Cipullo, R.; Polzone, C.; Talarico, G. Macromolecules 2003, 36, 2616. (b) Landis, C. R.; Sillars, D. R.; Douglass, R.; Batterton, J. M. J. Am. Chem. Soc. 2004, 126, 8890. (c) Busico, V.; Cipullo, R.; Romanelli, V.; Ronca, S.; Togrou, M. J. Am. Chem. Soc. 2005, 127, 1608.

(5) (a) Resconi, L. J. Mol. Catal. A 1999, 146, 167. (b) Landis, C. R.; Christianson, M. D. Proc. Natl. Acad. Sci. U.S.A. 2006, 103, 15349. (c) Bryliakov, K. P.; Talsi, E. P.; Semikolenova, N. V.; Zakharov, V. A.; Brand, J.; Alonso-Moreno, C.; Bochmann, M. J. Organomet. Chem. 2007, 692, 859.

(6) (a) Bochmann, M.; Lancaster, S. J. Angew. Chem., Int. Ed. Engl. 1994, 33, 1634. (b) Bochmann, M.; Lancaster, S. J. J. Organomet. Chem. 1995, 497, 55. (c) Babushkin, D. E.; Brintzinger, H. H. Chem.-Eur. J. 2007, 13, 5294.

(7) No differences with regard to speciation were detected between reaction systems containing either the dichloride or the dimethyl derivative.

(8) Addition of propene instead of 1-hexene gives rise to analogous observations, but with a new signal at $-1.62 \mathrm{ppm}$.

(9) Tritto, I.; Donetti, R.; Sacchi, M. C.; Locatelli, P.; Zannoni, G. Macromolecules 1997, 30, 1247; Macromolecules 1999, 32, 264.

(10) Under conditions leading to reduced polymerization rates, such as lower temperatures or use of commercial MAO solutions with higher $\mathrm{AlMe}_{3}$ content, instead of "dried" MAO (cf. Supporting Information) we also see reduced amounts of the cation $\left[(\mathrm{SBI}) \mathrm{Zr}(\mu-\mathrm{R})(\mu-\mathrm{Me}) \mathrm{AlMe}_{2}\right]^{+}$.

(11) For ${ }^{1} \mathrm{H}$ signals of $\left[(\mathrm{SBI}) \mathrm{Zr}\left(\mu-\mathrm{CH}_{2} \mathrm{SiMe}_{3}\right)(\mu-\mathrm{Me}) \mathrm{AlMe}_{2}\right]^{+}$with $\mathrm{B}\left(\mathrm{C}_{6} \mathrm{~F}_{5}\right)_{4}{ }^{-}$ as the counteranion, see Supporting Information.

(12) For each component of these single-proton signals, only about $1 / 12$ of the intensity of the $\mu-\mathrm{CH}_{3}$ signal at $-1.55 \mathrm{ppm}$ is to be expected, due to splitting by their diastereotopic counterparts and by the $\beta$-H atom.

(13) (a) Guo, Z.; Swenson, D. C.; Jordan, R. F. Organometallics 1994, 13, 1424. (b) Horton, A. D.; de With, J.; van der Linden, A. J.; van de Weg, H. Organometallics 1996, 15, 2675.

JA909157R 